\title{
Paideusis
}

\section{Le Québec en quête de laïcité [Quebec's pursuit of secularism] (Normand Baillargeon and Jean-Marc Piotte)}

\section{Bruce Maxwell}

Volume 20, Number 1, 2012

URI: https://id.erudit.org/iderudit/1071842ar

DOI: https://doi.org/10.7202/1071842ar

See table of contents

Publisher(s)

Canadian Philosophy of Education Society

ISSN

0838-4517 (print)

1916-0348 (digital)

Explore this journal

Cite this review

Maxwell, B. (2012). Review of [Le Québec en quête de laïcité [Quebec's pursuit of secularism] (Normand Baillargeon and Jean-Marc Piotte)]. Paideusis, 20(1), 33-35. https://doi.org/10.7202/1071842ar viewed online.

https://apropos.erudit.org/en/users/policy-on-use/ 
Paideusis, Volume 20 (2012), No. 1, pp. 33-35

Review of

\title{
Le Québec en quête de laïcité [Quebec's pursuit of secularism]
}

\author{
Edited by Normand Baillargeon and Jean-Marc Piotte, Montréal: Éditions \\ Écosociété, 2011.
}

\author{
BRUCE MAXWELL \\ Université du Québec à Trois-Rivières
}

If there is one public issue that best illustrates the distinctness of the contemporary political culture of Quebec from that of anglophone Canada, state secularism, la laïité, might well be it. Should civil servants, including public school teachers, be permitted to openly display signs of religious affiliation at work? Does a state curriculum that prescribes teaching about different religious traditions violate the principle of separation of religion and state? What does respect for freedom of conscience and religion require of public institutions, including schools, when they are faced with demands for special accommodation based on religious beliefs? These questions, now scarcely on the political radar in anglophone Canada, are presently among the most contested in Quebec public discourse.

The superficial explanation for their intractability here is circumstantial. Secularism was central to two widely publicized and deeply divisive recent events: the Bouchard-Taylor Commission on reasonable accommodation and the introduction of the Ethics and Religious Culture Programme into the provincial curriculum. The deeper explanation is historical. One of the defining victories of the Quiet Revolution was freedom for individuals and, at the state level, from the interference of religious authorities. The desire to protect this societal gain, often stoked by personal experiences of growing up under the yoke of the Catholic Church, contributes to a strong current of distrust toward religion in Quebec culture. Co-edited by Normand Baillargeon, a philosopher of education who is also a prominent public intellectual, this collection of commissioned essays is valuable as a source of insightful, rigorous and spirited treatments of issues such as the head scarf question, how to teach religion in schools, and the meaning of secularism in liberal democratic societies. For readers unfamiliar with the terms of the public debate over secularism in Quebec, it is a primer on one highly principled reading of secularism, "strict secularism", which has so far failed to take root elsewhere in North America.

The book's essays are organized around four questions that have largely characterized the debate over secularism in the past five years in Quebec. The first question is about which conception of secularism is right for contemporary Quebec society. Following the Bouchard-Taylor Report, the options under consideration are so-called "open secularism" and strict secularism, or secularism tout court as the proponents of this position in the book prefer to call it. According to the latter view, the secular state's obligation to remain at once neutral vis-à-vis the interests of religious groups and autonomous from the influence of religious authorities implies that state institutions must be free of all symbols of religious affiliation-from Duplessis' crucifix hanging over the president's chair in the

(C) Copyright 2012. Bruce Maxwell assigns to Paideusis the right of first publication and educational and non-profit institutions a non-exclusive license to use this document for personal use and in courses of instruction provided that the article is used in full and this copyright statement is reproduced. Any other usage is probibited without the express permission of the author. 
National Assembly to the hijab worn by the counter clerk at the Motor Vehicles Bureau. Open secularism, by contrast, prioritizes the individual's right to freedom of conscience and religion. The state's obligation to maintain an appearance of religious neutrality, in this view, applies to government institutions, not to government employees. Of the three essays that comprise this section, those by Guy Rocher and Daniel Baril reject open secularism, arguing that it amounts to permissiveness with regard to the encroachment of religious interests into the affairs of the government and thus, in the context of contemporary Quebec, an historical step backwards. Open secularism's defence is left in the hands of Daniel Weinstock who carefully reconstructs the principal arguments against open secularism and offers rejoinders to them.

Ostensibly, the question addressed in book's second section is whether it might be politically permissible to restrict the presence of religious symbols in public space. Given that this question is most often raised, in Quebec as elsewhere, primarily by those whose sensitivities are offended by the sight of Muslim women wearing head and face coverings in public, it is no small wonder that the personal, political and religious meaning of these practices emerge as a central theme in this section. And it is in this connection that the result of the editors' explicit choice to include only authors representing the liberal-progressive segment of the political spectrum becomes most manifest. Not one of these contributors-or indeed in the whole volume-entertains the idea of a global ban, in the manner of recent legislation in France, on the burka or niqab in public. All three of the main pieces dealing with this topic vigorously defend female civil servants' rights to wear religious symbols at work and the debate is focused on the hijab. While Jean-Marc Larouche's piece provides a résumé of his extensive 2008 study on the issue of the place of religion in postsecular societies, the particular strength of Jean-Marc Piotte's essay is to provide some refreshing sociological and historical context to the headscarf debate. Presenting her plea for open secularism using a narrative style, Francoise David, copresident of Québec solidaire, the province's emergent progressivist social democratic party, recounts the hostile reaction to a position statement arguing that allowing public sector employees to wear religious symbols is consistent with the principles of state secularism.

Quebec's new Ethics and Religious Culture (ERC) Programme is the focus of the third section of the book. Introduced in 2008, the Ethics and Religious Culture Programme aims to develop young people's skills in critical reflection and dialogue about ethical issues and to promote an understanding of the major religions using a comparative cultural approach. The two papers in this section take opposite sides on a controversy that continues to surround the programme: whether, for the purpose of teaching children and adolescents in schools, it is possible to distinguish between teaching for religious belief and teaching about religious belief. After a brief exposé on the history of the cultural approach to the study of religion - the techniques of which, we learn, were pioneered by a certain Jesuit missionary named Joseph-François Lafitau stationed in Kahnawake in the early eighteenth centuryLouis Rousseau defends the ethnographic conception of religious studies prescribed by the ERC programme. Since the aim of this approach, he argues, is to increase intercultural understanding rather than to promote religious belief, it is consistent with both the principle of separation of religion and state and the Charter right to individual freedom of conscience and religion. The hard-line atheist view is that religion deserves no place on a progressive naturalist curriculum and should have no formal representation in the government of a secular society because religions are irrational superstitions exploited by powerful interests to promote and justify sexism, homophobia, violent imperial conquest, slavery, etc. This perspective is represented by Marie-Michelle Poisson who, speaking as president of the Mouvement laïque québécois, recommends "the removal of the Religious Culture portion of the ERC programme but also the complete and final abolition of the [Provincial] Secretary of Religious Affairs and the Committee on Religious Affairs" (p. 177).

The fourth section of the book, titled "Le port du voile et la question des femmes" [The Veil and the Question of Women], closes the book with a set of three essays dealing with the headscarf debate. Considering that the hijab question was the central focus of two previous essays and that it was also repeatedly invoked as a test case about state secularism in the book's first section, it is not 
surprising that this section contains precious little new material. There may nevertheless be a certain heuristic value in the iteration of the arguments for and against allowing the bijab to be worn by civil servants. Indeed, one is left with two clear impressions.

The first impression is that this debate has much more to do with who has the power to control the way Muslim women represent their bodies in public than it does with how individual civil servants' religious beliefs might or might not prevent them from meeting their obligation to be impartial. If the genuine goal is to promote state secularism as a public value-by which it is meant that all levels of the state operate independently from the dictates of religious authority and that no religious groups receive privileged or prejudicial treatment at the hands of the state-then the proposed restriction on headscarves and other putative religious symbols can at best be regarded as a politically expedient halfmeasure. A far more effective policy would be to exclude religious believers from legislative bodies and the public service. But since such a policy option would be undemocratic, unconstitutional, and unpopular, a simple, fair, and apparently sensible solution (and, incidentally, a solution entertained by not one of the book's contributors) would be to apply the existing system of a posteriori controls. In the present case, such controls would sanction civil servants in the vanishingly rare cases where religious or ideological beliefs have been found to interfere with the impartial execution of their duties.

The second clear impression left by the final section of the book is that an infusion of some targeted sociological research may help move the debate forward. For instance, a question considered decisive by all sides is whether a ban on headscarves among public employees would binder the Muslim women's socio-economic integration into Quebec societies rather than facilitate it. Whatever the answer to this question, it is unlikely to be a simple "it does" or "it doesn't," but would rather involve a complex interaction of social factors.

Although Baillargeon and Piotte's intention to publish a more balanced collection of texts was undoubtedly honest, it was dashed by their authors' overwhelming preoccupation with a single issue. The good news is that if a reasonable settlement to the problem of openly religious symbols in the public workplace could be found, much of the present furor over secularism would likely subside. The bad news is that positions are deeply entrenched, and any compromise, especially for proponents of strict secularism, seems unlikely to be in the cards. Quebec's pursuit of secularism may be a long one yet.

\section{References}

Baillargeon, Normand, and Piotte, Jean-Marc. Le Québec en quête de laïcité [Quebec's pursuit of secularism]. Montréal: Éditions Écosociété, 2011. 